\title{
Pythium spp. Associated with Rooibos Seedlings, and Their Pathogenicity Toward Rooibos, Lupin, and Oat
}

Amirhossein Bahramisharif, Department of Plant Pathology, University of Stellenbosch, Private Bag X1, Matieland 7602, South Africa; Sandra C. Lamprecht, Agricultural Research Council-Plant Protection Research Institute, Private Bag X5017, Stellenbosch 7599, South Africa; Christoffel F. J. Spies, Department of Plant Pathology, University of Stellenbosch; Wilhelm J. Botha, ARC PPRI, Private Bag X134, Queenswood, Pretoria 0121, South Africa; Frikkie J. Calitz, Agricultural Research Council-Biometry, Hatfield Pretoria, 0083, South Africa; and Adéle McLeod, Department of Plant Pathology, University of Stellenbosch

\begin{abstract}
Bahramisharif, A., Lamprecht, S. C., Spies, C. F. J., Botha, W. J., Calitz, F. J., and McLeod, A. 2014. Pythium spp. associated with rooibos seedlings, and their pathogenicity toward rooibos, lupin, and oat. Plant Dis. 98:223-232.

Rooibos (Aspalathus linearis) is an important indigenous crop in South Africa. Oomycetes are a common problem in rooibos nurseries, causing serious losses, but limited information is available on the species involved. Molecular and morphological analyses of 117 oomycete isolates from 19 rooibos nurseries and 33 isolates from 11 native rooibos sites revealed the presence of several Pythium spp., including Pythium acanthicum, P. irregulare, P. mamillatum, P. myriotylum, P. pyrilobum, P. cederbergense, and Pythium RB II, and Phytophthora cinnamomi (native site). Most of the species were identified in nurseries and native rooibos, with Pythium irregulare being the most common species occurring in all nurseries and $46 \%$ of the native sites. Phylogenetic analyses of the internal transcribed spacer region of the $P$. irregulare isolates showed that isolates within this species complex fit

into three subclades, of which only two have previously been reported. On rooibos, all species except $P$. acanthicum and the previously characterized $P$. cederbergense and Pythium RB II were pathogenic and highly virulent. On lupin and oat, rotation crops in nurseries, the three aforementioned species were also nonpathogenic. All the other oomycete species were pathogenic on lupin but less so than on rooibos. On oat, only P. irregulare, P. myriotylum, and P. pyrilobum were pathogenic. This is the first report of $P$. mamillatum, $P$. pyrilobum, and $P$. myriotylum as pathogens of lupin, and $P$. irregulare and $P$. pyrilobum as pathogens of oat. The three nonpathogenic Pythium spp. were able to significantly reduce disease caused by pathogenic species in the less susceptible lupin and oat but not on rooibos. On lupin, the nonpathogenic species enhanced the virulence of Phytophthora cinnamomi.
\end{abstract}

The rooibos (Aspalathus linearis (N.L. Burm.) R. Dahlgr.) plant, which is well known for being used to produce herbal tea and a few other products, is only grown in the Cederberg Mountains in South Africa (27). The first step in rooibos production consists of seed being sown in open-bed nurseries in sandy soils, which are kept at field capacity. Approximately 4 months after sowing, the emerged seedlings are transplanted into commercial open-field production systems. In nurseries, special production practices are required for cultivating rooibos, because it is difficult to establish and grow seedlings. One of the main factors that affects establishment in nurseries is damping-off, which occurs within the first 6 weeks of rooibos seedling growth. Damping-off can cause serious losses in nurseries, generally in the order of $50 \%$ or more if no control measures are applied. Several plant pathogens, including Pythium, Fusarium, and Rhizoctonia spp., cause damping-off, with species within the genus Pythium being among the most prevalent and important pathogens (unpublished data).

The genus Pythium belongs to the phylum Oomycota, commonly known as oomycetes. Species within this genus are common in soils and have been reported from all over the world $(15,68)$. Many species are important soilborne plant pathogens that cause serious yield losses on a wide range of agricultural crops, including cereals, vegetables, shrubs, fruit trees, and ornamentals $(6,23$, 38,73). However, several species are saprophytic, with some

\section{Corresponding author: A. McLeod, E-mail: adelem@sun.ac.za}

* The $\boldsymbol{e}$-Xtra logo stands for "electronic extra" and indicates that two additional tables are available in the online edition.

Accepted for publication 23 August 2013.

http://dx.doi.org/10.1094/PDIS-05-13-0467-RE

(C) 2014 The American Phytopathological Society species even enhancing plant growth and showing potential as biocontrol agents $(37,68)$. For example, Pythium acanthicum Drechsler, P. oligandrum Drechsler, and P. periplocum Drechsler are effective in suppressing damping-off caused by $P$. ultimum Trow, $P$. irregulare Buiman, $P$. mamillatum Meurs, $P$. myriotylum Drechsler, and $P$. vexans de Bary $(1,36,55,68)$. P oligandrum is also antagonistic toward Phytophthora parasitica Dastur (51), Rhizoctonia solani Kühn and Fusarium culmorum (W.G. Sm.) Sacc. (11). On apple (Malus domestica Borkh.), several undescribed Pythium spp. (Pythium MM1, Pythium MM3 [aff. oedochilum], and Pythium MM5 [aff. vexans]) have shown biocontrol potential, because they were able to suppress root rot on apple seedlings caused by Pythium sylvaticum Campb. \& F.F. Hendrix and P. ultimum (40).

In South Africa, rooibos growers must use an integrated management approach for managing Pythium damping-off, where several cultural practices, biological control, and fungicides could potentially be combined. Several fungicides (metalaxyl, metalaxylM, mancozeb, thiram, captab, dazomet, and dichlorophen) are registered in South Africa for the management of Pythium diseases (46), of which metalaxyl-M is known to be very effective (59). However, fungicides may not be applied in organic rooibos production systems and, therefore, only biological control and cultural practices (water management, fertilizer applications, organic amendments, and crop rotation) may be used $(16,25,28,42,45)$. Of the cultural practices, water management is very important because excess water and soil moisture favors Pythium spp. reproduction and infection (20). Rotation crops and organic amendments can sometimes be effective at suppressing soilborne diseases, including those caused by Pythium spp. $(10,17,24)$, but little is known about their effect in rooibos production systems and whether rotation crops such as lupin and oat are hosting rooibos soilborne pathogens. Biological control also has potential for the management of Pythium damping-off in some crop systems $(21,35,45,47,54,71)$ but its potential has not yet been investigated in rooibos. The only 
biocontrol agent that is registered for Pythium root rots in South Africa is Trichoderma harzianum Rifai (N. Mkize, Department of Agriculture, Forestry and Fisheries, directorate Food Safety and Quality Assurance, South Africa, personal communication).

The genus Pythium consists of more than 106 species that can be identified using morphological and DNA data (60). At the DNA level, Pythium spp. can be identified through polymerase chain reaction (PCR) amplification of the internal transcribed spacer (ITS) regions, followed by PCR restriction fragment length polymorphisms (RFLPs) or sequencing $(34,41)$. Phylogenetic analysis of ITS sequence data has revealed the presence of 11 phylogentic clades (A to K) within the genus (34). The validity of several species within some of these clades has been questioned. For example, in clade F, Garzón et al. (19) identified two distinct species, $P$. cryptoirregulare and $P$. irregulare s.s., within the $P$. irregulare species complex. However, Spies et al. (63) provided evidence suggesting that all currently described species within the $P$. irregulare complex (P. cryptoirregulare, $P$. cylindrosporum, $P$. irregulare, and $P$. regulare) form a single phylogenetic species that is genetically diverse.

Very little is known about the specific Pythium spp. and other oomycetes such as Phytophthora that are associated with rooibos and their pathogenicity toward rooibos and two nursery rotation crops (lupin [Lupinus angustifolius L.] and oat [Avena sativa L.]). Previously, only two Pythium clade G taxa (P. cederbergense and Pythium RB II) were identified from rooibos, which were shown to be nonpathogenic toward rooibos, lupin, and oat (2). Knowledge of the specific oomycete species involved and their pathogenicity is important, because this will allow for the future development of molecular detection and quantification methods, which can be used to monitor the effectiveness of different management strategies. The aims of our study were to determine (i) the oomycete species associated with rooibos seedlings in 19 nurseries, (ii) whether the species in native rooibos ecosystems (mature plants in native ecosystem) are similar to those in nurseries, (iii) the pathogenicity of oomycete species toward rooibos and two rotation crops (lupin and oat), and (iv) whether nonpathogenic oomycete species could suppress disease caused by pathogenic species on rooibos, lupin, and oat (i.e., if a biological control effect was evident).

\section{Materials and Methods}

Survey and isolations from rooibos nurseries and native ecosystems. Rhizosphere soils from 19 rooibos nurseries were sampled from a depth of $20 \mathrm{~cm}$ in March and April and in June and July 2007 to 2009 . Rhizosphere soils were also collected from rooibos plants in 11 native ecosystems (Table 1). The rhizosphere soils were collected by uprooting the plants and vigorously shaking the roots, which allowed collection of the soil adhering to the roots. The soil was used in a glasshouse trial, where rooibos seed were sown in the different soils and kept at temperatures of approximately $18^{\circ} \mathrm{C}$ (night) and $27^{\circ} \mathrm{C}$ (day). After 4 weeks, the roots of damped-off seedlings were plated onto Pythium and Phytophthora

Table 1. Occurrence of oomycete species (Pythium and Phytophthora) in rooibos nurseries and native rooibos

\begin{tabular}{|c|c|c|c|c|c|c|c|c|}
\hline \multirow[b]{2}{*}{ Location $^{y}$} & \multicolumn{8}{|c|}{ Percent isolates (number of isolates) ${ }^{x}$} \\
\hline & P. cinn & P. aca & P. irregulare $^{\mathrm{Z}}$ & P. mam & P. $m y r$ & P. pyr & P. ced & RB II \\
\hline \multicolumn{9}{|l|}{ Nursery } \\
\hline A & 0 & $8(1)$ & 8 (1) PY1, 46 (6) PY2, 8 (1) PY4, 22 (3) PY8 & 0 & $8(1)$ & 0 & 0 & 0 \\
\hline B & 0 & 0 & 11 (1) PY2, 45 (4) PY4, 33 (3) PY5 & 0 & 0 & 0 & 0 & $11(1)$ \\
\hline $\mathrm{C}$ & 0 & 0 & 5 (1) PY1, 29 (5) PY2, 56 (10) PY4, 5 (1) PY5 & 0 & 0 & 0 & 0 & $5(1)$ \\
\hline $\mathrm{D}$ & 0 & 0 & 8 (1) PY1, 17 (2) PY2, 25 (3) PY4, 50 (6) PY8 & 0 & 0 & 0 & 0 & 0 \\
\hline E & 0 & 0 & 44 (3) PY1, 14 (1) PY2, 14 (1) PY4, 14 (1) PY8, 14 (1) Py11 & 0 & 0 & 0 & 0 & 0 \\
\hline $\mathrm{F}$ & 0 & 0 & 25 (1) PY4, 25 (1) Py8, 50 (2) PY11 & 0 & 0 & 0 & 0 & 0 \\
\hline G & 0 & 0 & 20 (1) PY1, 80 (4) PY2 & 0 & 0 & 0 & 0 & 0 \\
\hline $\mathrm{H}$ & 0 & 0 & 100 (5) PY4 & 0 & 0 & 0 & 0 & 0 \\
\hline I & 0 & $17(1)$ & 17 (1) PY11 & $17(1)$ & $49(3)$ & 0 & 0 & 0 \\
\hline $\mathrm{J}$ & 0 & 0 & 33 (1) PY4 & $67(2)$ & 0 & 0 & 0 & 0 \\
\hline $\mathrm{K}$ & 0 & 0 & 33 (2) PY4 & 0 & $67(4)$ & 0 & 0 & 0 \\
\hline $\mathrm{L}$ & 0 & 0 & 33 (1) PY2, 33 (1) PY4 & 0 & $33(1)$ & 0 & 0 & 0 \\
\hline M & 0 & 0 & 100 (1) PY2 & 0 & 0 & 0 & 0 & 0 \\
\hline $\mathrm{N}$ & 0 & 0 & 7 (1) PY2, 7 (1) PY5, 7 (1) PY11 & 0 & $50(7)$ & 0 & $22(3)$ & $7(1)$ \\
\hline $\mathrm{O}$ & 0 & 0 & 40 (2) PY1, 40 (2) PY2, 20 (1) PY4 & 0 & 0 & 0 & 0 & 0 \\
\hline $\mathrm{P}$ & 0 & 0 & 100 (1) PY4 & 0 & 0 & 0 & 0 & 0 \\
\hline $\mathrm{Q}$ & 0 & 0 & 100 (1) PY4 & 0 & 0 & 0 & 0 & 0 \\
\hline $\mathrm{R}$ & 0 & 0 & 33 (1) PY1, 67 (2) PY2 & 0 & 0 & 0 & 0 & 0 \\
\hline $\mathrm{S}$ & 0 & 0 & 100 (1) PY2 & 0 & 0 & 0 & 0 & 0 \\
\hline Total & 0 & $2(2)$ & $\begin{array}{l}9 \text { (10) PY1, } 23 \text { (27) PY2, } 27 \text { (32) PY4, } 4 \text { (5) PY5, } \\
9 \text { (11) PY8, } 4 \text { (5) PY11 }\end{array}$ & $3(3)$ & $13(16)$ & 0 & $3(3)$ & $3(3)$ \\
\hline \multicolumn{9}{|l|}{ Native } \\
\hline A & & & 33 (1) PY4 & & & & $67(2)$ & \\
\hline B & & & 100 (9) PY4 & & & & & \\
\hline $\mathrm{C}$ & & & & $50(2)$ & & $50(2)$ & & \\
\hline $\mathrm{D}$ & $20(1)$ & & & & & $40(2)$ & $40(2)$ & \\
\hline $\mathrm{E}$ & & & 100 (3) PY2 & & & & & \\
\hline $\mathrm{F}$ & & & & $100(1)$ & & & & \\
\hline $\mathrm{G}$ & & & & $100(1)$ & & & & \\
\hline $\mathrm{H}$ & & & 100 (1) PY4 & & & & & \\
\hline I & & & & & & & $100(1)$ & \\
\hline $\mathrm{J}$ & & & 100 (1) PY2 & & & & & \\
\hline $\mathrm{K}$ & & & & & & $75(3)$ & $25(1)$ & \\
\hline Total & $3(1)$ & 0 & 12 (4) PY2, 34 (11) PY4 & $12(4)$ & 0 & $21(7)$ & $18(6)$ & 0 \\
\hline \multirow[t]{2}{*}{$\mathrm{N}+\mathrm{N}^{\mathrm{z}}$} & $1(1)$ & $1(2)$ & 7 (10) PY1, 21 (31) PY2, 29 (43) PY4, 3 (5) PY5, & & & & & \\
\hline & & & 8 (11) PY8, 3 (5) PY11 & $4(7)$ & $11(16)$ & $4(7)$ & $6(9)$ & $2(3)$ \\
\hline
\end{tabular}


selective media (PARP and PARPH, respectively; 6,26). Isolations from glasshouse-grown roots were more effective for isolating pathogens compared with isolations that were made from fieldgrown plant roots, where many saprophytic and secondary microbes from old roots interfered with pathogen isolation (unpublished data). Hyphae emerging from the plated roots were hyphal tipped to cornmeal agar (CMA; Sigma Aldrich), followed by a second hyphal tipping. All isolates were stored as CMA culture plugs in sterile deionized water containing grass blades, as V8-agar (18) plugs in sterile deionized water, and on potato-carrot agar (14) slant cultures at $15^{\circ} \mathrm{C}$.

Molecular species identification. Oomycete isolates were grown on V8 agar for 5 to 7 days. Aerial mycelium was harvested and genomic DNA was extracted from a total of 150 isolates using a slight modification of the cetyltrimethylammonium bromide method of Lee and Taylor (32), as previously described (67).

PCR-RFLP analyses. The ITS region of the isolates was amplified from DNA using primers ITS6 (7) and ITS4 (72). The PCR reaction consisted of $1 \times$ PCR buffer (Bioline), $2.5 \mathrm{mM} \mathrm{MgCl}_{2}, 0.2$ $\mathrm{mM}$ dNTPs, $0.65 \mathrm{U}$ of BIOTAQ (Bioline), bovine serum albumin Fraction V (Roche Diagnostics South Africa) at $0.05 \mathrm{mg} / \mathrm{ml}$, and $0.2 \mathrm{mM}$ each primer in a total reaction volume of $40 \mu \mathrm{l}$. Amplifications were performed in a 2720 Applied Biosystems thermal cycler with an initial denaturation at $94^{\circ} \mathrm{C}$ for $5 \mathrm{~min}$; followed by $32 \mathrm{cy}-$ cles of $94^{\circ} \mathrm{C}$ for $30 \mathrm{~s}$, annealing for $30 \mathrm{~s}$ at $55^{\circ} \mathrm{C}$, and extension at $72^{\circ} \mathrm{C}$ for $90 \mathrm{~s}$; and 1 cycle of extension at $72^{\circ} \mathrm{C}$ for $7 \mathrm{~min}$. PCR products were resolved in $1 \%$ agarose gels and DNA fragments were visualized by staining in a solution of ethidium bromide. Successfully amplified PCR products were restriction digested with enzymes HinfI and HhaI in a single reaction (41), according to the manufacturer's instructions (Fermentas Inc.). Because some of the PCR-RFLP patterns, such as Py1versus Py4 and Py8 versus Py11, were not easily differentiated from each other based on the HinfI and HhaI digest (see Results section) due to light bands not always being reproducible, the PCR products of isolates belonging to these PCR-RFLP groups and all groups identified as $P$. irregulare were also digested using only enzyme $H$ haI. This allowed for a more accurate identification of the $P$. irregulare PCR-RFLP groups when used in conjunction with the HinfI and HhaI data. The PCR-RFLP products were run on a $3 \%$ agarose gel, and isolates that had the same RFLP pattern were assigned to the same RFLP group.

ITS sequencing. The ITS regions of at least two isolates of each PCR-RFLP group were sequenced and double-strand consensus sequences were obtained, as previously described (41). The sequences were submitted to BLAST analyses in GenBank, and identified to species level using sequences submitted by Lévesque and De Cock (34).

Phylogenetic analyses of $\mathrm{P}$. irregulare. The genetic diversity among the $P$. irregulare isolates was analyzed phylogenetically. Two to three isolates representative of each of the six $P$. irregulare PCR-RFLP patterns (see Results) were selected for sequencing. The PCR product of one of the isolates (R8282W1) was cloned and sequenced, as previously described (63), because direct sequencing yielded poor quality sequence data. The ITS consensus sequences were submitted to GenBank (KC855063, KC855064, KC855065, KC855066, KC855067, KC855068, KC855069, KC855070, KC855071, KC855072, KC855073, KC855074, $\mathrm{KC} 855075$, and KC855076). The reference sequences used in the analyses included species that fit into Pythium clade F and sequences representative of all the $P$. irregulare subclades identified by Spies et al. (63).

Maximum parsimony analyses of Pythium clade F was conducted as previously described (63). Bayesian analyses were conducted using MrBayes v. 3.0b4 (58) and the program MrModeltest (53) was used to select the optimal model of sequence evolution, as previously described (44). The selected model for the ITS region was HKY, with an estimated proportion of invariable sites $(+\mathrm{I})$ and an estimated $\gamma$ parameter $(+\mathrm{G})$. The first 433,100 generations (burn-in) were discarded for the ITS analysis.
Morphological identification of oomycete species. Morphological identification of all Pythium isolates were conducted as previously described (44). Phytophthora spp. were identified using Erwin and Ribeiro (16).

Pathogenicity assays. A subset of 32 isolates was selected for inclusion in pathogenicity assays on lupin, oat, and rooibos. The isolates represented all the different species that were identified from nurseries and the native ecosystems (Table 1), except for $P$. cederbergense and Pythium RB II that were not included in the pathogenicity studies because the pathogenicity of these groups has previously been established (2). The selected isolates included one Phytophthora cinnamomi isolate, two isolates of Pythium acanthicum, 16 isolates of $P$. irregulare that represented all six PCR-RFLP groups identified for this species (see Results), three $P$. mamillatum isolates, six isolates of $P$. myriotylum, and four isolates of $P$. pyrilobum.

Pathogenicity assays were conducted in a glasshouse pot trial. A pasteurized planting medium (equal parts of soil, perlite, and sand) was inoculated with sand and wheat bran inoculum of each of the oomycete isolates at a concentration of $0.05 \%$ inoculum/planting medium (wt/wt). The sand-wheat bran inoculum was prepared as previously described $(2,30)$. The control consisted of planting medium inoculated with sand-wheat bran that was inoculated with uncolonized agar plugs. Plastic pots $(13 \mathrm{~cm}$ in diameter) were filled with $800 \mathrm{~g}$ of the inoculated media. Ten planting holes were made for seed in each pot to a depth of $1.5 \mathrm{~cm}$ (rooibos) to $2 \mathrm{~cm}$ (lupin and oat). The number of seed planted per pot was 50 for rooibos and oat and 20 for lupin. Three replications were included for each treatment and the trial was conducted twice. The pots were watered almost on a daily basis in order to keep the soil at field capacity. The experiments were carried out in the glasshouse at temperatures of approximately $18^{\circ} \mathrm{C}$ (night) and $27^{\circ} \mathrm{C}$ (day).

Pathogenicity of the isolates was determined by evaluating seedling length and percent survival. The survival of seedlings in all three crops was evaluated 2 weeks after planting. The seedling length of the surviving seedlings was measured for lupin and oat 2 weeks after planting but, for rooibos, it was only evaluated after 1 month, because rooibos is a very slow grower and only cotyledons are present 2 weeks after planting. Roots were not evaluated for rot, because previous studies showed that the analysis was too subjective, and that seedling length and survival provided more accurate data (unpublished data). Reisolations were made from the roots, if available, or from damped-off seed to fulfill Koch's postulates (67).

Evaluating the potential of nonpathogenic Pythium spp. to suppress damping-off caused by pathogenic oomycete species. The ability of nonpathogenic Pythium spp. to suppress damping-off caused by pathogenic oomycete species was assessed on rooibos, lupin, and oat using a sand-wheat bran inoculation method, as described above. The oomycete species that were used included all the species that were identified from rooibos in the current study (Table 1). Each species was represented by only one isolate and included the nonpathogenic species $P$. acanthicum (R8206Q), Pythium RB II (STE-U 7548), and P. cederbergense (STE-U 7555) and the pathogenic species Phytophthora cinnamomi (R8303A), Pythium irregulare (R8308F), P. mamillatum (R8201C), $P$. myriotylum (R8197F), and P. pyrilobum (R8198A) (see Results section). The isolates that were used to represent pathogenic species were all pathogenic toward lupin and rooibos, whereas only $P$. irregulare (R8308F), P. myriotylum (R8197F), and P. pyrilobum (R8298A) were pathogenic toward oat (see Results section). In each mixed-species inoculation treatment (M1 to M7), each isolate in the mixture was first inoculated separately into sand-wheat bran medium and, after 10 days of growth, the colonized sand-wheat bran of different species was co-inoculated into the planting medium. Each isolate in the mixture was inoculated at a concentration of $0.05 \%(\mathrm{wt} / \mathrm{wt})$. The trial included seven treatments and three replicates per treatment and was conducted twice. The seven treatments and the specific species used in the co-inoculations consisted of M1, a mixture of pathogenic oomycetes spp. (Phy- 
tophthora cinnamomi, Pythium irregulare, P. mamillatum, $P$. myriotylum, and P. pyrilobum) and nonpathogenic Pythium spp. ( $P$. acanthicum, $P$. cederbergense, and Pythium RB II); M2, a mixture of only pathogenic oomycetes species (Phytophthora cinnamomi, Pythium irregulare, P. mamillatum, P. myriotylum, and P. pyrilobum); M3, a mixture of only nonpathogenic Pythium spp. (P. acanthicum, $P$. cederbergense, and Pythium RB II); M4, a mixture of $P$. irregulare and nonpathogenic Pythium spp. (P. acanthicum, $P$. cederbergense, and Pythium RB II); M5, a mixture of Phytophthora cinnamomi and nonpathogenic Pythium spp. (Pythium acanthicum, P. cederbergense, and Pythium RB II); M6, only $P$. irregulare; and M7, only Phytophthora cinnamomi. The control consisted of uncolonized sand-bran medium inoculated at $0.05 \%$ (wt/wt) into the planting medium.

Statistical analyses. The plant length and percent survival data were subjected to an appropriate analysis of variance for both trials. Levene's test was conducted for homogeneity of trials (33) and, finally, the data of the two trials were combined and subjected to analysis of variance. The means of significant source effects were compared using Student's $t$-LSD ( $t$ least significant difference) at a 5\% significance level. The Shapiro-Wilk test was performed on standardized residuals to test for deviations from normality (62). All of the above procedures were performed by SAS statistical software (version 9.2; SAS Institute Inc.).

\section{Results}

Survey and isolations from rooibos nurseries and native ecosystems. Oomycete isolates, mainly Pythium spp., were obtained from all the surveyed nursery and native rooibos soils. The only other oomycete genus that was identified was Phytophthora, which was represented by one isolate from native rooibos. In total, 150 oomycete isolates, 117 from the 19 nurseries and 33 from the 11 native ecosystems, were obtained and characterized further.

Molecular and morphological identification of oomycete species. ITS-PCR-RFLP analyses using HinfI and HhaI revealed the presence of 14 different groups (PY1 to PY14; Table 1; Fig 1). Some of the light bands characteristic for some of the Py groups, such as PY1 versus PY4 and PY 5 versus PY 8 (Fig. 1), were not always readily differentiated and visible on gels but enzyme digestion using only $H h a \mathrm{I}$ was helpful in differentiating these groups from each other (Fig. 2). GenBank BLAST analyses of the ITS sequences of representative isolates of each of the PCR-RFLP groups showed that Pythium irregulare was represented by six PCR-RFLP groups (PY1, 2, 4, 5, 8, and 11), PY3 was P. myriotylum, PY6 was $P$. mamillatum, PY7 was $P$. pyrilobum, PY9 was $P$. cinnamomi, PY10 was $P$. acanthicum, $P$. cederbergense was PY 12 , and Pythium RB II was represented by two groups (PY 13 and 14). For the PCR-RFLP groups of P. irregulare, PY4 (29\%) and PY2 (21\%) were most abundant, followed by PY8 (8\%), PY1 (7\%),
PY5 (3\%), and PY11 (3\%) (Table 1). Morphological analyses of all the oomycete isolates corresponded to the molecular identifications.

In nurseries, six Pythium taxa were identified, with $P$. irregulare being isolated from all the nurseries and dominating populations, comprising 76\% (90/117) of all nursery isolates (Table 1). The next most abundant species in nurseries were P. myriotylum $(13 \%)$, followed by P. mamillatum (3\%), P. cederbergense (3\%), Pythium RB II (3\%), and P. acanthicum (2\%). In contrast to native rooibos where $P$. pyrilobum was one of the prevalent species, this species and Phytophthora cinnamomi were not detected in nurseries (Table 1).

The species composition of Pythium populations differed among the 19 nurseries (Table 1). The highest species diversity was found in nurseries I and $\mathrm{N}$ (four species each). In nursery N, Pythium irregulare, P. myriotylum, $P$. cederbergense, and Pythium RB II were identified, whereas nursery I contained $P$. acanthicum, $P$. irregulare, $P$. mamillatum, and $P$. myriotylum. In both nurseries, $P$. myriotylum was the dominating (approximately 50\%) species. Pythium populations in nursery $\mathrm{K}$ consisted of $P$. irregulare and $P$. myriotylum and were also dominated by $P$. myriotylum. $P$. irregulare was detected in all the nurseries, whereas $P$. myriotylum was only identified in five nurseries. The lowest number of Pythium isolates was detected in nurseries $\mathrm{M}, \mathrm{P}, \mathrm{Q}$, and $\mathrm{S}$, where only one isolate of $P$. irregulare was recovered in each nursery. In most $(58 \%)$ of the nurseries, P. irregulare was also the only Pythium sp. detected. Furthermore, in all nurseries where more than two $P$.

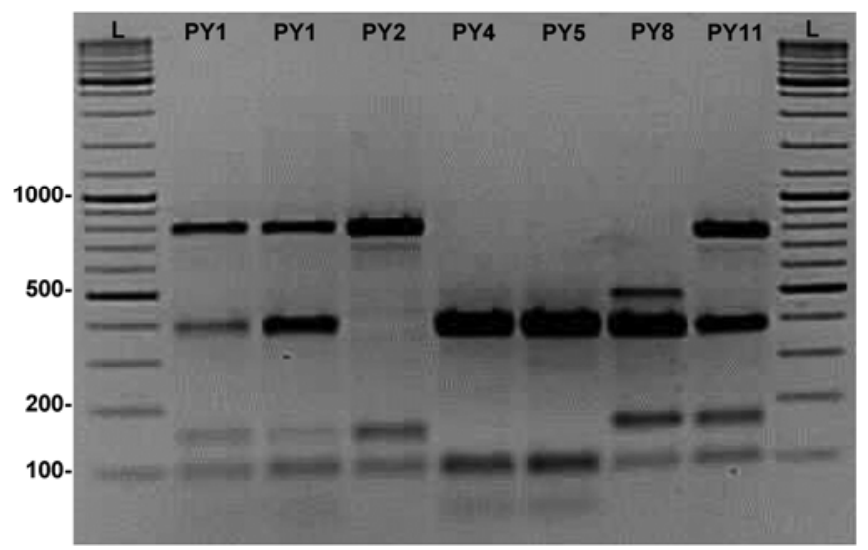

Fig. 2. Six polymerase chain reaction $(P C R)$ restriction fragment length polymorphism (RFLP) groups (PY1, PY2, PY4, PY5, PY8, and PY11) that were identified among Pythium irregulare isolates from rooibos. The PCR-RFLP groups were identified by conducting a single restriction digestion with Hhal on PCRamplified products of the internal transcribed spacer regions. A 100-bp DNA ladder (L) was used to estimate the size of digested products.

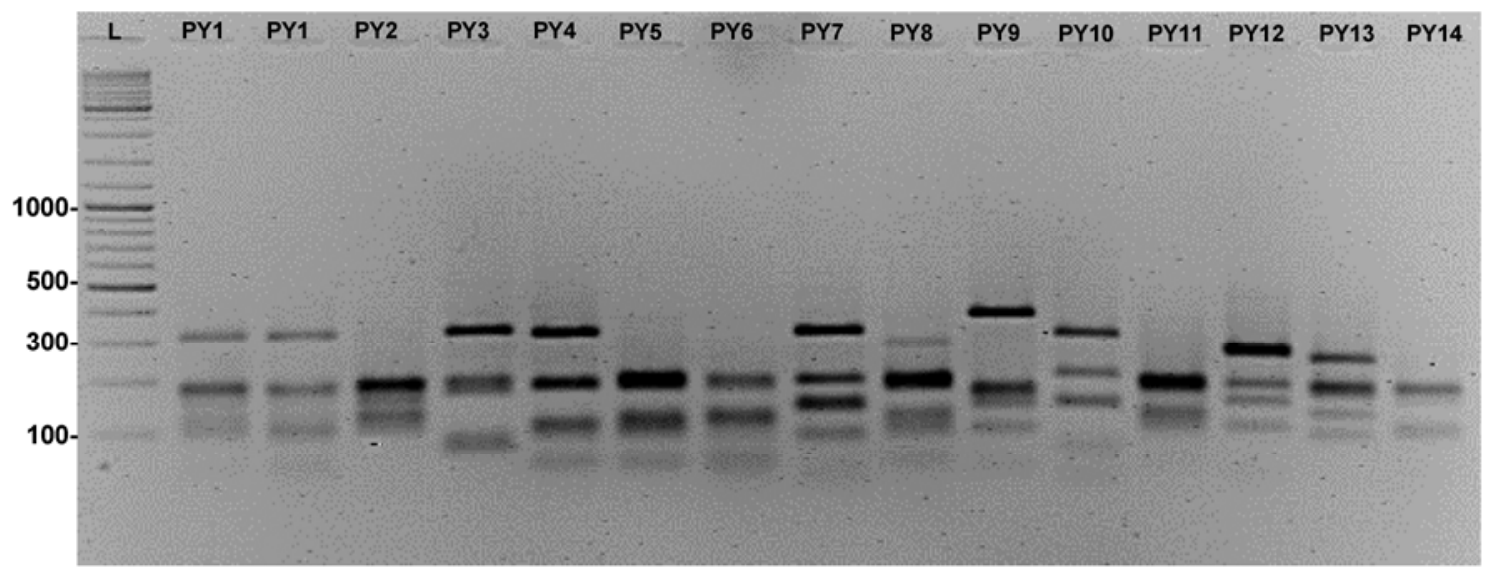

Fig. 1. Fourteen polymerase chain reaction (PCR) restriction fragment length polymorphism (RFLP) groups (PY1 to PY14) that were identified among oomycete (Pythium and Phytophthora) isolates obtained from rooibos. The PCR-RFLP groups were identified by conducting a double-restriction digestion with Hinfl and Hhal on PCR-amplified products of the internal transcribed spacer regions. A 100 bp DNA ladder $(\mathrm{L})$ was used to estimate the size of digested products. 
irregulare isolates were obtained, at least two but up to five (nursery E) different $P$. irregulare PCR-RFLP groups were identified, except for nursery $\mathrm{H}$, where all five isolates belonged to the same PCR-RFLP group (Table 1).

Among the 33 oomycete isolates obtained from native rooibos soils, $P$. irregulare was also the dominant $(46 \%)$ species, followed by $P$. pyrilobum $(21 \%)$, P. cederbergense (18\%), and P. mamillatum (12\%). Phytophthora cinnamomi (3\%) was represented by only one isolate. Pythium irregulare was also the most common species among the different sites, occurring in 5 of the 11 sites, followed by $P$. cederbergense that was identified in 4 of the native sites. The $P$. irregulare PCR-RFLP groups identified in the native rooibos did not differ from those in the cultivated nurseries and included all five groups. In contrast to the nurseries where $P$. myriotylum was the second most abundant species, this species, along with $P$. acanthicum and Pythium RB II, was not identified from native rooibos (Table 1).

Phylogenetic analyses of $\boldsymbol{P}$. irregulare. Maximum parsimony and Bayesian analyses of the ITS region clustered the rooibos $P$. irregulare sequences into a single well-supported clade (97\% bootstrap support, 1.00 probability) containing the entire $P$. irregulare species complex (Fig. 3). This clade was further subdivided into three subclades with good bootstrap and probability support. Subclade A ( $87 \%$ bootstrap, 1.00 probability) corresponded to subclades 1 and 2 of Spies et al. (63) and includes GenBank sequences of $P$. irregulare CBS 250.28 (ex-neotype strain), P. cryptoirregulare CBS 118731 (ex-holotype strain), and 11 rooibos isolates that represented four of the rooibos PCR-RFLP groups (PY1, PY4, PY8, and PY11). The second subclade (subclade B, 100\% bootstrap support, 1.00 probability) corresponded to subclade 3 of Spies et al. (63) and includes GenBank sequences of P. cryptoirregulare CBS 118731 (ex-holotype strain), P. cylindrosporum CBS 218.94 (ex-type strain), and $P$. regulare CI-34 (holotype strain) but no rooibos isolate sequences. The third subclade (subclade C, 99\% bootstrap support, 1.00 probability) represents a novel $P$. irregulare subclade that was not identified by Spies et al. (63). This subclade only contained sequences of three rooibos isolates (R8177A, R8173N, and R8292AE) that all belonged to PCR-RFLP group Py5, and a GenBank $P$. irregulare sequence (HQ643604) from the study of Robideau et al. (57).

Pathogenicity assays. There was not enough evidence $(P>$ $0.05)$ against homogeneity of variances of the two trials for seedling survival and length based on Levene's variance ratio test and, therefore, the data of the two trials could be combined. From the analysis of variance Table (Supplementary Table S1), there was strong evidence for significant isolate-crop, species-crop, and PCR-RFLP group-crop interactions for percent survival $(P<$ $0.0001)$ and seedling length $(P<0.0001)$. Therefore, it is appropriate to calculate the $t$-LSD in order to compare the interaction means within rows and within columns.

Most oomycete isolates and species were pathogenic toward rooibos. All the isolates of Phytophthora cinnamomi, Pythium irregulare, P. mamillatum, P. myriotylum, and P. pyrilobum were highly virulent on rooibos, causing $100 \%$ seedling damping-off (Table 2). P. acanthicum was the only nonpathogenic species, because it did not cause a significant decrease in rooibos seedling survival or seedling length compared with the uninoculated control (Table 2).

Several of the Pythium spp. and Phytophthora cinnamomi were pathogenic toward lupin. P. cinnamomi, Pythium irregulare, $P$. mamillatum, $P$. myriotylum, and $P$. pyrilobum were all considered pathogenic toward lupin because some isolates within each species significantly reduced the survival of lupin seedlings (Table 2) and caused a significant reduction in seedling length compared with the uninoculated control (Table 2). However, the isolates were less virulent than on rooibos, causing on average 40 to $60 \%$ dampingoff. Similar to rooibos, $P$. acanthicum was also nonpathogenic toward lupin and did not cause a significant effect on the survival or length of lupin seedlings (Table 2). All the P. irregulare isolates were pathogenic toward lupin, causing a significant reduction in seedling survival and length, with the exception of isolate R8304C (PY4), which only caused a significant reduction in seedling length (Table 2). The $P$. irregulare isolates differed in virulence toward lupin; for example, isolate R8308F (PY2) caused significantly more seedling damping-off than most of the other $P$. irregulare isolates, with the exception of R8160L (Py8) (Table 2). Only one (R8201C) of the three P. mamillatum isolates was pathogenic and caused a significant reduction in seedling survival and length compared with the uninoculated control, whereas the other two isolates did not (Table 2). All the P. myriotylum isolates were pathogenic, because all the isolates caused a significant reduction in seedling length and survival, with the exception of isolate R8166K1 that was less virulent and only caused a significant reduction in seedling length. The $P$. pyrilobum isolates were all pathogenic, causing a significant reduction in seedling survival and length. One of the P. pyrilobum isolates (R8303J) was highly virulent, causing significantly more seedling damping-off than all of the other oomycete isolates (Table 2).

The pathogenicity assays on oat revealed that some isolates in $P$. irregulare, $P$. myriotylum, and $P$. pyrilobum were pathogenic, causing significantly less seedling survival (Table 2) and a significant reduction in seedling length (Table 2) when compared with the uninoculated control. Most isolates were not highly virulent and caused less than $30 \%$ damping-off, with the exception of some $P$. myriotylum isolates that caused more than $50 \%$ damping-off. All Phytophthora cinnamomi, Pythium acanthicum, and P. mamillatum isolates were nonpathogenic and did not cause a significant reduction in seedling survival or length (Table 2). Similar to what was found on lupin, isolates within species differed in their pathogenicity. Four of the P. irregulare isolates (R8129Q, R8304C, R8307N, and $\mathrm{R} 8161 \mathrm{C}$ ) were nonpathogenic and did not cause a significant reduction in seedling length or survival. The remaining $P$. irregulare isolates were pathogenic, causing a significant reduction in seedling length, although only a few isolates (R8162D, R8167A, R8171D, and R8160A) were able to cause a significant reduction in seedling survival. Only three (R8169S, R8197F, and R8204F) of the six $P$. myriotylum isolates were pathogenic, causing a significant reduction in seedling survival (Table 2) and length (except isolate R8169S) compared with the uninoculated control (Table 2). All the $P$. pyrilobum isolates were pathogenic, causing a significant reduction in seedling survival and length (Table 2).

Evaluating the potential of nonpathogenic Pythium spp. to suppress damping-off caused by pathogenic oomycete species. In co-inoculation pathogenicity assays, there was not enough evidence $(P>0.05)$ against homogeneity of variances of the two repeat trials for seedling survival and length; thus, the data of the two repeat trials were combined. There was not enough evidence for significant interaction $(P \geq 0.05)$ between the trial and other factors; therefore, a combined analysis with six replicates (blocks with trials) was performed. The analyses of variance on the percent survival and seedling length showed a significant treatment-crop interaction $(P<0.0001)$ (Supplementary Table S2). Therefore, it was appropriate to calculate the interaction $t$-LSD to compare the interaction means within rows and within columns (Table 3 ).

The co-inoculation of pathogenic (Phytophthora cinnamomi, Pythium irregulare, $P$. mamillatum, $P$. myriotylum, and $P$. pyrilobum) species and nonpathogenic Pythium spp. (P. acanthicum, $P$. cederbergense, and Pythium RB II) showed that nonpathogenic species were effective in suppressing disease only in the less susceptible crops lupin and oat but not on rooibos (Table 3). On rooibos, the presence of nonpathogenic Pythium spp. along with pathogenic oomycete species still resulted in 100\% damping-off of seedlings (Table 3). On lupin, when several pathogenic oomycete species were present (M1), nonpathogenic species resulted in a significant increase in seedling length but no significant effect was seen for a reduction in damping-off (Table 3). In contrast, when only $P$. irregulare was inoculated on lupin, the nonpathogenic Pythium spp. (M4) were able to suppress disease and caused a significant increase in seedling survival and length compared with when only P. irregulare (M6) was present (Table 3). It was unex- 
pected to find that, when nonpathogenic Pythium spp. were combined with Phytophthora cinnamomi (M5), a significant reduction in seedling survival was observed compared with when only $P$. cinnamomi (M7) was present. On oat, co-inoculation of nonpatho- genic Pythium spp. with pathogenic oomycete species (M1), resulted in a significantly higher survival rate and length of oat seedlings compared with when only pathogenic species were present (M2) (Table 3). It should be noted, however, that the Pythium

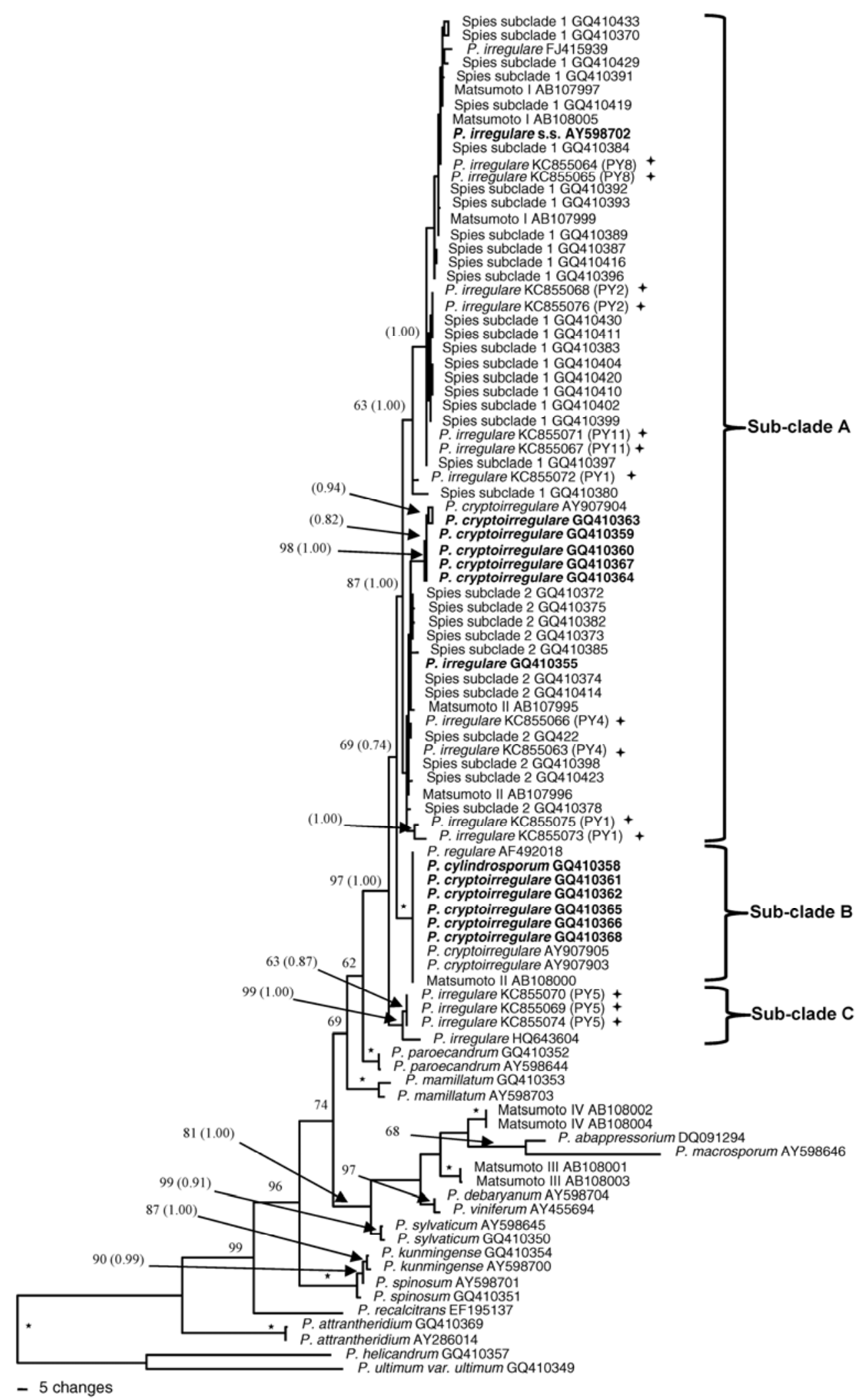

Fig. 3. Phylogeny of Pythium irregulare collected from rooibos and Pythium clade $F(34,63)$ based on the internal transcribed spacer region of nuclear ribosomal DNA. The tree is one of 920 equally parsimonious trees of a heuristic search. Rooibos isolates are indicated by a + symbol. CBS reference isolates are indicated in bold. Numbers in the tree represent parsimony bootstrap support values followed by posterior probabilities (in parentheses). Bootstrap support of $100 \%$ and a probability value of 1.00 are indicated by a star symbol $(\star)$. Bootstrap support less than $60 \%$ and probability values less than 0.70 are not indicated. Tree length $(\mathrm{TL})=923 ; \mathrm{consistency} \mathrm{index}(\mathrm{Cl})=$ 0.691 ; retention index $(\mathrm{RI})=0.854$; rescaled consistency index $(\mathrm{RC})=0.590$; homoplasy index $(\mathrm{HI})=0.309$. 
mamillatum and Phytophthora cinnamomi isolates in the pathogenic species mix were nonpathogenic toward oat (Tables 2 and 3 ). On oat, the Pythium irregulare isolate by itself only caused a reduction in seedling length but, when nonpathogenic species were added, this reduction in length was significantly reduced (Table 3).

\section{Discussion}

Several oomycete species were found associated with rooibos grown in nurseries and in native rooibos sites in the Western Cape Province of South Africa. Most of the oomycete species consisted of Pythium spp., including Pythium acanthicum, P. irregulare, $P$. mamillatum, $P$. myriotylum, $P$. pyrilobum, $P$. cederbergense, and Pythium RB II, but one Phytophthora sp., Phytophthora cinnamomi, was also identified. The species composition in the rooibos nurseries and the native sites was similar with regards to the predominance by Pythium irregulare and the occurrence of $P$. mamillatum. P. acanthicum, P. myriotylum, and Pythium RB II were only identified in nurseries. Phytophthora cinnamomi and Pythium pyrilobum were only detected in the native sites. The detection of Phytophthora cinnamomi in a native site might be due to this species being the most virulent and widespread pathogen of the indigenous family Proteaceae $(13,70)$ that is native to the region where rooibos naturally occurs. The oomycete species identified from rooibos in the current study do not include any new species reports from South Africa $(9,44)$; however, this is the first report of these species being associated with rooibos.

In several but not all rooibos locations, more than one oomycete species was associated with rooibos. In the native rooibos sites, up to three different species were identified from the same site, with most sites containing only two species. Two of the rooibos nurseries contained four species. In both of these nurseries, Pythium myriotylum dominated the populations. The prevalence of one Pythium sp. and several species being associated with a specific host is not uncommon, and has been reported for several crops, including wheat (Triticum aestivum L.), grapevine (Vitis vinifera L.), apple, and carrot (Daucus carota L.). On these crops, the species composition was also found to differ with location $(40,49,64,65)$. Biological traits such as pathogenicity, optimum temperature for mycelial growth, and saprophytic survival of inoculum could explain the fluctuations in Pythium spp. composition (65). Several abiotic soil properties can also affect Pythium community composition in soil, including $\mathrm{pH}$, calcium, magnesium, and field capacity (4).

P. irregulare, a genetically diverse species, is an important pathogen of rooibos due to its prevalence and high virulence toward

Table 2. Percent survival and seedling length of lupin, oat, and rooibos seedlings grown in soil inoculated with different Pythium isolates, Phytophthora cinnamomi, and an uninoculated control

\begin{tabular}{|c|c|c|c|c|c|c|}
\hline \multirow[b]{2}{*}{ Species, isolate ${ }^{\mathrm{z}}$} & \multicolumn{3}{|c|}{ Survival $(\%)^{x}$} & \multicolumn{3}{|c|}{ Length $(\mathbf{m m})^{y}$} \\
\hline & Lupin & Oat & Rooibos & Lupin & Oat & Rooibos \\
\hline Control & 74.1 & 94.6 & 94.0 & 111.4 & 136.2 & 32.8 \\
\hline \multicolumn{7}{|l|}{ P. cinnamomi } \\
\hline R8303A (PY9) & 38.3 & 94.3 & 0.0 & 71.6 & 151.0 & - \\
\hline \multicolumn{7}{|l|}{ Pythium acanthicum } \\
\hline R8162U (PY10) & 63.3 & 93.3 & 92.0 & 103.5 & 141.3 & 23.5 \\
\hline R8206Q (PY10) & 70.8 & 95.3 & 89.7 & 109.0 & 140.5 & 28.5 \\
\hline \multicolumn{7}{|l|}{ P. irregulare } \\
\hline R8282W1 (PY1) & 55.0 & 88.0 & 0.0 & 84.9 & 117.6 & - \\
\hline R8294C (PY1) & 60.0 & 86.0 & 0.0 & 70.7 & 114.2 & - \\
\hline R8162D (PY2) & 52.5 & 82.0 & 0.0 & 88.1 & 112.6 & - \\
\hline R8167A (PY2) & 60.0 & 80.0 & 0.0 & 76.9 & 116.5 & - \\
\hline R8171D (PY2) & 51.6 & 79.0 & 0.0 & 61.9 & 115.1 & - \\
\hline R8308F (PY2) & 35.8 & 88.7 & 0.0 & 65.2 & 114.0 & - \\
\hline R8129Q (PY4) & 59.1 & 89.7 & 0.0 & 92.2 & 131.4 & - \\
\hline R8304C (PY4) & 65.8 & 89.7 & 0.0 & 88.0 & 125.5 & - \\
\hline R8307N (PY4) & 60.0 & 92.7 & 0.0 & 92.8 & 125.5 & - \\
\hline R8161C (PY4) & 62.5 & 91.3 & 0.0 & 96.9 & 129.2 & - \\
\hline R8244H (PY4) & 59.1 & 91.0 & 0.0 & 97.6 & 121.5 & - \\
\hline R8168I (PY11) & 58.3 & 84.0 & 0.0 & 86.3 & 106.5 & - \\
\hline R8177A (PY5) & 61.6 & 92.7 & 0.0 & 80.8 & 119.4 & - \\
\hline R8292AE (PY5) & 55.8 & 86.0 & 0.0 & 86.4 & 112.5 & - \\
\hline R8160A (PY8) & 57.5 & 79.0 & 0.0 & 72.0 & 109.0 & - \\
\hline R8160L (PY8) & 46.6 & 84.0 & 0.0 & 62.1 & 104.0 & - \\
\hline \multicolumn{7}{|l|}{ P. mamillatum } \\
\hline R8201C (PY6) & 45.0 & 91.0 & 0.0 & 88.6 & 126.0 & - \\
\hline R8296C (PY6) & 65.0 & 88.0 & 0.0 & 100.5 & 124.0 & - \\
\hline R8302D (PY6) & 75.0 & 91.7 & 0.0 & 106.5 & 125.2 & - \\
\hline \multicolumn{7}{|l|}{ P. myriotylum } \\
\hline R8128T (PY3) & 51.6 & 89.0 & 0.0 & 88.7 & 131.6 & - \\
\hline R8130U (PY3) & 51.6 & 84.3 & 0.0 & 76.4 & 126.1 & - \\
\hline R8166K1 (PY3) & 63.3 & 93.0 & 0.0 & 96.5 & 130.0 & - \\
\hline R8169S (PY3) & 41.6 & 69.6 & 0.0 & 67.3 & 124.5 & - \\
\hline R8197F (PY3) & 35.0 & 48.3 & 0.0 & 52.4 & 104.5 & - \\
\hline R8204F (PY3) & 48.3 & 57.3 & 0.0 & 59.8 & 101.8 & - \\
\hline \multicolumn{7}{|l|}{ P. pyrilobum } \\
\hline R8298A (PY7) & 55.8 & 77.6 & 0.0 & 79.0 & 106.9 & - \\
\hline R8302F (PY7) & 57.5 & 67.6 & 0.0 & 89.1 & 111.0 & - \\
\hline R8303D (PY7) & 42.5 & 75.3 & 0.0 & 80.6 & 111.8 & - \\
\hline R8303J (PY7) & 26.6 & 66.0 & 0.0 & 46.5 & 108.6 & - \\
\hline
\end{tabular}

${ }^{\mathrm{x}}$ Seedling survival was evaluated 2 weeks after planting seed. Values are the mean of three replicates, and data that were pooled over two trials. Least significant difference $(\mathrm{LSD} ; P=0.05)=11.38$.

${ }^{y}$ Length of lupin and oat seedlings was determined 2 weeks after sowing seed, and after 4 weeks for rooibos. Values are the mean of three replicates, and data that were pooled over two trials; - indicates no seedlings survived. LSD $(P=0.05)=12.88$.

${ }^{\mathrm{z}}$ Internal transcribed spacer region polymerase chain reaction restriction fragment length (ITS-PCR-RFLP) group (PY1 to PY11) to which each isolate belonged to are indicated in parentheses. 
rooibos. All of the nurseries contained $P$. irregulare and, in most of the nurseries (58\%), only P. irregulare was identified. Six different PCR-RFLP groups were identified for the nursery isolates. The same PCR-RFLP groups also occurred in the native sites, where $P$. irregulare was also prevalent, occurring in $46 \%$ of the sites. Phylogenetic analyses of representatives of the different $P$. irregulare PCR-RFLP groups showed that isolates from rooibos were genetically diverse at the ITS level, as previously reported $(3,19,34,39)$. The rooibos isolates fit into two subclades within the $P$. irregulare species complex, which include one novel subclade when compared with the subclades identified by Spies et al. (63). BLAST analyses would suggest that some of the rooibos $P$. irregulare isolates could have been identified as $P$. cryptoirregulare but the validity of this species has been questioned (63). Therefore, all the rooibos isolates were considered to be $P$. irregulare. The diversity in $P$. irregulare was also evident in pathogenicity studies toward oat and lupin but there was no correlation between the observed genetic variation and variation in pathogenicity. On oat, not all of the $P$. irregulare isolates were pathogenic whereas, on lupin, some isolates differed in virulence. Spies et al. (64) also identified nonpathogenic $P$. irregulare isolates among pathogenic isolates on grapevine. Variation in virulence among $P$. irregulare isolates has also been reported on barrel medic (Medicago truncatula Gaertn.), subclover (Trifolium subterraneum L.), and wheat (22). Variation in pathogenicity and virulence among $P$. myriotylum isolates, as has been identified in the current study, have also been reported on cocoyam (Xanthosoma sagittifolium (L.) Schott) (50), tomato (Solanum lycopersicum L.), rye (Secale cereal L.), oat, wheat, sorghum (Sorghum bicolor (L.) Moench), peanut (Arachis hypogaea L.), bean (Phaseolus vulgaris L.), tobacco (Nicotiana tabacum L.), and soybean (Glycine max (L.) Merr.) (43).

Several of the rooibos-associated oomycete species were shown to be highly virulent toward rooibos and less virulent on the two rotation crops lupin and oat. Almost all oomycete species associated with rooibos, except Pythium acanthicum and the previously characterized $P$. cederbergense and Pythium RB II, were highly virulent toward rooibos, causing 100\% damping-off. All the species that were pathogenic on rooibos were also pathogenic on lupin but, on oat, only $P$. irregulare, $P$. myriotylum, and $P$. pyrilobum were pathogenic. $P$. irregulare is known as a highly virulent species with a very wide host range $(5,9,31,38,48,69)$ and has been reported as a pathogen of lupin $(66,68)$ but not of oat. Phytophthora cinnamomi has also been reported as a pathogen of lupin (61) and Pythium myriotylum as a pathogen of oat (43). Thus, this is the first report of $P$. mamillatum, $P$. pyrilobum, and $P$. myriotylum as pathogens of lupin and $P$. irregulare and $P$. pyrilobum as pathogens of oat. Although $P$. mamillatum and $P$. myriotylum have not been reported as pathogens of lupin, they have been reported as pathogens of other legume crops, including peanut, cowpea (Vigna unguicu- lata (L.) Walp.), soybean (pathogen: P. myriotylum), and kidney bean (Phaseolus vulgaris L.; pathogens: Pythium mamillatum and P. myriotylum $)(38,52,56)$. $P$. pyrilobum has not been reported as a pathogen of other legume crops. Although $P$. irregulare and $P$. pyrilobum have not been reported as pathogens of oat, $P$. irregulare has been reported as a pathogen of wheat and $P$. pyrilobum as a pathogen of rice (it only reduced root growth but did not reduce shoot growth or seedling survival; 5,8). Although $P$. acanthicum has not been reported as a pathogen of oat and lupin or other legume and grain crops, it has been reported as a pathogen of tomato (68) and watermelon (68). Considering the wide host range and diversity of oomycete species associated with rooibos, it might be difficult to find a rotation crop that is a nonhost and that can significantly reduce oomycete inoculum levels.

Nonpathogenic Pythium spp. (P. acanthicum, P. cederbergense, and Pythium RB II) showed potential for suppressing damping-off caused by $P$. irregulare or a combination of oomycetes (Phytophthora cinnamomi, Pythium irregulare, $P$. mamillatum, $P$. myriotylum and $P$. pyrilobum) on lupin and oat but not on rooibos. On lupin, the nonpathogenic Pythium spp. caused a significant reduction in symptoms caused by $P$. irregulare and by a combination of pathogenic oomycetes (Phytophthora cinnamomi, Pythium irregulare, P. mamillatum, P. myriotylum, and P. pyrilobum). It was unexpected that the combination of Phytophthora cinnamomi and nonpathogenic Pythium spp. resulted in a significant increase in damping-off on lupin, compared with when only P. cinnamomi was present. This suggests that there might be a synergistic interaction between $P$. cinnamomi and the nonpathogenic Pythium spp. in causing disease on lupin. On oat, the nonpathogenic Pythium spp. were able to significantly reduce disease incited by the combination of oomycete species and when only Pythium irregulare was present. However, it should be noted that, in the mixture of isolates that was used, the only isolates that were pathogenic toward oat were $P$. irregulare, $P$. myriotylum, and $P$. pyrilobum. However, the control achieved with all of the aforementioned nonpathogenic species was marginal because some only increased seedling length but did not decrease damping-off. Furthermore, where damping-off was suppressed, the level of control was not comparable with the uninoculated control, as growers often expect when applying a management treatment. Improved disease suppression might be obtained if more isolates of the nonpathogenic species are evaluated, because biological control isolates are known to vary in efficacy, with some isolates being superior in suppressing specific diseases on specific crops. In the future, it will also be important to evaluate the biocontrol efficacy using naturally infested pathogen field soils and artificial inoculation of the nonpathogens, because the current study evaluated the biocontrol potential using artificial inoculation of pathogens into a pasteurized potting mix. This will also determine whether the nonpathogens will be able to establish

Table 3. Percent survival and length of lupin, oat and rooibos seedlings grown in soil co-inoculated with different combinations of Pythium spp. (pathogenic and nonpathogenic) and Phytophthora cinnamomi

\begin{tabular}{|c|c|c|c|c|c|c|}
\hline \multirow[b]{2}{*}{ Treatment } & \multicolumn{3}{|c|}{ Survival $(\%)^{\mathrm{w}}$} & \multicolumn{3}{|c|}{ Length $(\mathbf{m m})^{x}$} \\
\hline & Lupin & Oat & Rooibos & Lupin & Oat & Rooibos \\
\hline Control & $69.2 \mathrm{ef}$ & $93.0 \mathrm{ab}$ & $96.7 \mathrm{a}$ & $120.4 \mathrm{ef}$ & $146.5 \mathrm{ab}$ & $33.4 \mathrm{i}$ \\
\hline M1 (pathogenic oomycete spp. and nonpathogenic Pythium spp.) & $45.0 \mathrm{hi}$ & 74.7 def & $0.0 \mathrm{k}$ & $90.7 \mathrm{~g}$ & $133.1 \mathrm{~cd}$ & - \\
\hline M2 (pathogenic oomycete spp.) y $^{\mathrm{y}}$ & $40.8 \mathrm{i}$ & $53.7 \mathrm{gh}$ & $0.0 \mathrm{k}$ & $65.0 \mathrm{~h}$ & $101.6 \mathrm{~g}$ & - \\
\hline M3 (nonpathogenic spp.) ${ }^{\mathrm{z}}$ & $66.7 \mathrm{f}$ & $90.3 \mathrm{ab}$ & $93.0 \mathrm{ab}$ & $125.9 \mathrm{de}$ & $144.1 \mathrm{bc}$ & $33.1 \mathrm{i}$ \\
\hline M4 (Pythium irregulare and nonpathogenic Pythium spp. $)^{\mathrm{z}}$ & $55.8 \mathrm{~g}$ & $79.0 \mathrm{cde}$ & $0.0 \mathrm{k}$ & $92.7 \mathrm{~g}$ & $130.5 \mathrm{de}$ & - \\
\hline M5 (Phytophthora cinnamomi and nonpathogenic Pythium spp.) ${ }^{2}$ & $19.2 \mathrm{j}$ & $85.0 \mathrm{bcd}$ & $0.0 \mathrm{k}$ & $76.0 \mathrm{~h}$ & $157.0 \mathrm{a}$ & - \\
\hline M6 (Pythium irregulare) & $35.8 \mathrm{i}$ & $88.7 \mathrm{abc}$ & $0.0 \mathrm{k}$ & $67.8 \mathrm{~h}$ & $114.0 \mathrm{f}$ & - \\
\hline M7 (Phytophthora cinnamomi) & $38.3 \mathrm{i}$ & $94.3 \mathrm{ab}$ & $0.0 \mathrm{k}$ & $71.1 \mathrm{~h}$ & $151.0 \mathrm{ab}$ & - \\
\hline
\end{tabular}

${ }^{\text {w}}$ Means followed by the same letter do not differ significantly at $P=0.05$. Seedling survival was evaluated 2 weeks after planting seed. Values are the mean of three replicates, and data that were pooled over two trials. Least significant difference (LSD; $P=0.05)=10.64$.

${ }^{x}$ Means followed by the same letter do not differ significantly at $P=0.05$. The length of lupin and oat seedlings was determined 2 weeks after sowing seed, and after 4 weeks for rooibos. Values are the mean of three replicates, and data that were pooled over two trials; - indicates no seedlings survived. LSD $(P$ $=0.05)=11.90$.

y The same pathogenic oomycete species were included in treatment M1 and M2 and consisted of one isolate each of Phytophthora cinnamomi, Pythium irregulare, P. mamillatum, P. myriotylum, and P. pyrilobum.

${ }^{\mathrm{z}}$ Nonpathogenic species consisted of one isolate each of $P$. acanthicum, Pythium RB II, and P. cederbergense. 
in a natural field soil where a consortium of native microbes are already present.

The suppression of Pythium diseases by species within the same genus has previously been reported by a few other studies. $P$. acanthicum was able to reduce damping-off caused by $P$. ultimum on cucumber (1) and damping-off caused by $P$. irregulare and $P$. $m a$ millatum on sugar beet (55). P. periplocum and P. oligandrum have been reported to reduced damping-off of sugar beet caused by $P$. ultimum (55). Ribeiro and Butler (55) also showed that P. irregulare and $P$. mamillatum were highly susceptible to $P$. oligandrum and $P$. periplocum, while $P$. myriotylum was highly susceptible to $P$. periplocum. Phytophthora cinnamomi was only marginally suppressed by Pythium acanthicum and $P$. periplocum (55). The three modes of parasitism implicated in disease suppression by mycoparasitic Pythium spp. include lysis, cytoplasmic coagulation, and penetration of the host at the point of contact $(29,55)$.

The current study showed that $P$. irregulare is a prominent and virulent pathogen of rooibos, along with several other pathogenic species that were less frequently found. Most of the pathogenic rooibos species were also pathogenic toward two nursery rotation crops, lupin and oat. On these crops, there were fewer species and isolates that were pathogenic toward oat, and the species were also less virulent on oat and lupin than on rooibos. The reduced number of species and isolates pathogenic toward oat compared with lupin could explain field observations that lupin as a pre-crop significantly increased damping-off of rooibos whereas oat did not (unpublished data). The biocontrol effect of oat has previously been demonstrated in a study by Deacon and Mitchell (12) that showed that oat roots attract and lyse zoospores of several Pythium spp. ( $P$. aphanidermatum (Edson) Fitzp., $P$. arrhenomanes Drechsler, $P$. graminicola Subraman., P. intermedium de Bary, P. ultimum var. sporangiiferum Drechsler), and Phytophthora cinnamomi. Oat roots were also found to inhibit oospore formation and germination, due to the release of fungitoxic compounds from the roots (12). The effective use of oat as a rotation crop will have to be evaluated further in glasshouse and field trials. It will also be important to determine whether oat can result in an increase in nonpathogenic oomycete species that could help suppress pathogenic species on oat and, perhaps, on rooibos. Ultimately this, along with disease incidence, will determine whether oat will form an important part of an integrated management strategy of rooibos damping-off caused by oomycetes. The use of nonpathogenic Pythium spp. as biocontrol agents in rooibos nurseries as a standalone treatment did not show promise, because it did not suppress damping-off on rooibos. It is also of concern that, on lupin, the nonpathogenic species enhanced the virulence of $P$. cinnamomi.

\section{Acknowledgments}

We thank the South African Rooibos Council, Stellenbosch University, and the National Research Foundation for funding the research.

\section{Literature Cited}

1. Ali-Shtayeh, M. S., and Saleh, A. S. F. 1999. Isolation of Pythium acanthicum, P. oligandrum, and P. periplocum from soil and evaluation of their mycoparasitic activity and biocontrol efficacy against selected phytopathogenic Pythium species. Mycopathologia 145:143-153.

2. Bahramisharif, A., Lamprecht, S. C., Spies, C. F. J., Botha, W. J., and McLeod, A. 2013. Pythium cederbergense sp. nov. and related taxa from Pythium clade G associated with the South African indigenous plant Aspalathus linearis (rooibos). Mycologia. 105:1174-1189.

3. Barr, D. J. S., Warwick, S. I., and Desaulniers, N. L. 1997. Isozyme variation, morphology, and growth response to temperature in Pythium irregulare. Can. J. Bot.75:2073-2081.

4. Broders, K. D., Wallhead, M. W., Austin, G. D., Lipps, P. E., Paul, P. A., Mullen, R. W., and Dorrance, A. E. 2009. Association of soil chemical and physical properties with Pythium species diversity, community composition, and disease incidence. Phytopathology 99:957-967.

5. Chamswarng, C., and Cook, R. J. 1985. Identification and comparative pathogenicity of Pythium species from wheat roots and wheat-field soils in the Pacific Northwest. Phytopathology 75:821-827.

6. Chellemi, D. O., Mitchell, D. J., Kannwischer-Mitchell, M. E., Rayside, P. A., and Rosskopf, E. N. 2000. Pythium spp. associated with bell pepper production in Florida. Plant Dis. 84:1271-1274.

7. Cooke, D. E., and Duncan, J. M. 1997. Phylogenetic analysis of Phy- tophthora species based on ITS1 and ITS2 sequences of the ribosomal RNA gene repeat. Mycol. Res. 101:667-677.

8. Cother, E. J., and Gilbert, R. L. 1993. Comparative pathogenicity of Pythium species associated with poor seedling establishment of rice in Southern Australia. Plant Pathol. 42:151-157.

9. Crous, P. W., Phillips, A. J. L., and Baxter, A. P. 2000. Phytopathogenic Fungi from South Africa. Department of Plant Pathology Press, University of Stellenbosch, South Africa.

10. Davison, E. M., and McKay, A. G. 2003. Host range of Pythium sulcatum and the effects of rotation on Pythium diseases of carrots. Australas. Plant Pathol. 32:339-346.

11. Deacon, J. W. 1976. Studies on Pythium oligandrum, an aggressive parasite on other fungi. Trans. Br. Mycol. Soc. 66:383-391.

12. Deacon, J. W., and Mitchell, R. T. 1985. Toxicity of oat roots, oat root extracts, and saponins to zoospores of Pythium spp. and other fungi. Trans. Br. Mycol. Soc. 84:479-487.

13. Denman, S., and Sadie, A. 2001. Evaluation of a stem inoculation technique for assessing resistance to Phytophthora cinnamomi in Leucospermum cultivars. Australas. Plant Pathol. 30:11-16.

14. Dhingra O. D., and Sinclair, J. S. 1985. Basic Plant Pathology Methods. CRC Press, Boca Raton, FL.

15. Dick, M. W. 1990. Keys to Pythium. University of Reading, Reading, UK.

16. Erwin, D. C., and Ribeiro, O. K. 1996. Phytophthora Diseases Worldwide. American Phytopathological Society, St. Paul, MN.

17. Fry, W. E. 1982. Principles of Plant Disease Management. Academic Press, New York.

18. Galindo, J., and Gallegly, M. E. 1960. The nature of sexuality in Phytophthora infestans. Phytopathology 50:123-128.

19. Garzón, C. D., Yánez, J. M., and Moorman, G. W. 2007. Pythium cryptoirregulare, a new species within the P. irregulare species complex. Mycologia 99:291-301.

20. Gubler, W. D., Baumgartner, K., Browne, G. T., Eskalen, A., Rooney Latham, S., Petit, S., and Bayramian, L. A. 2004. Root diseases of grapevines in California and their control. Australas. Plant Pathol. 33:157-165.

21. Hadar, Y., Harman, G. E., and Taylor, A. G. 1984. Evaluation of Trichoderma koningii and T. harzianum from New York soils for biological control of seed rot caused by Pythium spp. Phytopathology 74:106-110.

22. Harvey, P.R., Butterworth, P.J., Hawke, B.G., and Pankhurst, C.E. 2001. Genetic and pathogenic variation among cereal, medic and sub-clover isolates of Pythium irregulare. Mycol. Res. 105:85-93.

23. Higginbotham, R. W., Paulitz, T. C., and Kidwell, K. K. 2004. Virulence of Pythium species isolated from wheat fields in eastern Washington. Plant Dis. 88:1021-1026.

24. Hoitink, H. A. J., and Changa, C. M. 2004. Production and utilization guidelines for disease suppressive composts. Acta Hortic. 635:87-92.

25. Hoitink, H. A. J., Stone, A. G., and Han, D. Y. 1997. Suppression of plant diseases by composts. HortScience 32:184-187.

26. Jeffers, S. N., and Martin, S. B. 1986. Comparison of two media selective for Phytophthora and Pythium species. Plant Dis. 70:1038-1043.

27. Joubert, E., Gelderblom, W. C. A., Louw, A., and de Beer, D. 2008. South African herbal teas: Aspalathus linearis, Cyclopia spp. and Athrixia phylicoides—a review. J. Ethnopharmacol. 119:376-412.

28. Ko, W. H., and Kao, C. W. 1989. Evidence for the role of calcium in reducing root disease incited by Pythium spp. Pages 205-217 in: Soilborne Plant Pathogens: Management of Diseases with Macro- and Microelements. A. E. Engelhard, ed. American Phytopathological Society, St. Paul, MN.

29. Laing, S. A. K., and Deacon, J. W. 1991. Video microscopy comparison of mycoparasitism by Pythium oligandrum, P. nunn and an unnamed Pythium species. Mycol. Res. 95:469-479.

30. Lamprecht, S. C. 1986. A new disease of Medicago truncatula caused by Cylindrocladium scoparium. Phytophylactica 18:111-114.

31. Larkin, R. P., English, J. T., and Mihail, J. D. 1995. Identification, distribution and comparative pathogenicity of Pythium spp. associated with alfalfa seedlings. Soil Biol. Biochem. 27:357-364.

32. Lee, S. B., and Taylor, J. W. 1990. Isolation of DNA from fungal mycelia and single spores. Pages 282-287 in: PCR Protocols: A Guide to Methods and Applications. M. A. Innis, D. H. Gelfand, J. J. Sninsky, and T. J. White, eds. Academic Press, New York.

33. Levene, H. 1960. Robust test in the equality of variance. Pages 278-292 in: Contributions to Probability and Statistics. I. Olkin, ed. Stanford University Press, Palo Alto, CA.

34. Lévesque, C. A., and De Cock, A. W. A. M. 2004. Molecular phylogeny and taxonomy of the genus Pythium. Mycol. Res. 108:1363-1388.

35. Loper, J. E. 1988. Role of fluorescent siderophore production in biological control of Pythium ultimum by a Pseudomonas fluorescens strain. Phytopathology 78:166-172.

36. Martin, F. N., and Hancock, J. G. 1987. The use of Pythium oligandrum for biological control of pre-emergence damping off caused by $P$. ultimum. Phytopathology 77:1013-1020.

37. Martin, F. N., and Loper, J. E. 1999. Soilborne plant diseases caused by Pythium species: ecology, epidemiology, and prospects for biological control. Crit. Rev. Plant Sci. 18:111-181.

38. Matoba, Y., Kondo, N., Akino, S., Kodama, F., Naito, S., and Ebe, S. 2008. Identification and pathogenicity of Pythium species causing damping-off of 
kidney bean. J. Gen. Plant Pathol. 74:81-85

39. Matsumoto, C., Kageyama, K., Suga, H., and Hyakumachi, M. 2000. Intraspecific DNA polymorphisms of Pythium irregulare. Mycol. Res. 104:1333-1341.

40. Mazzola, M., Andrews, P. K., Reganold, J. P., and Lévesque, C. A. 2002. Frequency, virulence, and metalaxyl sensitivity of Pythium spp. isolates from apple roots under conventional and organic production systems. Plant Dis. 86:669-675.

41. Mazzola, M., Brown, J., Zhao, X., Izzo, A. D., and Fazio, G. 2009. Interaction of brassicaceous seed meal and apple rootstock on recovery of Pythium spp. and Pratylenchus penetrans from roots grown in replant soils. Plant Dis. 93:51-57.

42. Mazzola, M., and Gu, Y. H. 2000. Impact of wheat cultivation on microbial communities from replant soils and apple growth in greenhouse trials. Phytopathology 90:114-119.

43. McCarter, S. M., and Littrell, R. H. 1970. Comparative pathogenicity of Pythium aphanidermatum and Pythium myriotylum to twelve plant species and interaspecific variation in virulence. Phytopathology 60:264-268.

44. McLeod, A., Botha, W. J., Meitz, J. C., Spies, C. F. J., Tewoldemedhin, Y. T., and Mostert, L. 2009. Biodiversity of Pythium species in South African agricultural systems. Mycol. Res. 113:933-951.

45. Naseby, D. C., Pascual, J. A., and Lynch, J. M. 2000. Effect of biocontrol strains of Trichoderma on plant growth, Pythium ultimum populations, soil microbial communities and soil enzyme activities. J. Appl. Microbiol. 88:161-169.

46. Nel, A., Krause, M., and Khelawanlall, N. 2003. A Guide for the Control of Plant Diseases, 2nd ed. Department of Agriculture, Pretoria, South Africa.

47. Nelson, E., Van Dijk, K., Kageyama, K., and Windstam, S. 2004. Biological control of soilborne diseases: important concepts from a model system. Acta Hortic. 635:115-130.

48. Pankhurst, C. E., McDonald, H. J., and Hawke, B. G. 1995. Influence of tillage and crop rotation on the epidemiology of Pythium infections of wheat in a red-brown earth of South Australia. Soil Biol. Biochem. 27:1065-1073

49. Paulitz, T. C., and Adams, K. 2003. Composition and distribution of Pythium communities in wheat fields in eastern Washington state. Phytopathology 93:867-873.

50. Perneel, M., Tambong, J., Adiobo, A., Floren, C., Saborío, F., Lévesque, A., and Höfte, M. 2006. Intraspecific variability of Pythium myriotylum isolated from cocoyam and other host crops. Mycol. Res. 110:583-593.

51. Picard, K., Tirilly, Y., and Benhamou, N. 2000. Cytological effects of cellulases in the parasitism of Phytophthora parasitica by Pythium oligandrum. Appl. Environ. Microbiol. 66:4305-4314.

52. Porter, D. M. 1970. Peanut wilt caused by Pythium myriotylum. Phytopathology 60:393-394.

53. Posada, D., and Crandall, K. A. 1998. Modeltest: testing the model of DNA substitution. Bioinformatics 14:817-818.

54. Quagliotto, L., Azziz, G., Bajsa, N., Vaz, P., Pérez, C., Ducamp, F., Cadenazzi, M., Altier, N., and Arias, A. 2009. Three native Pseudomonas fluorescens strains tested under growth chamber and field conditions as biocontrol agents against damping-off in alfalfa. Biol. Control 51:42-50.

55. Ribeiro, W. R. C., and Butler, E. E. 1995. Comparison of the mycoparasites Pythium periplocum, P. acanthicum and P. oligandrum. Mycol. Res. 99:963-969.
56. Rizvi, S. S. A., and Yang, X. B. 1996. Fungi associated with soybean seedling disease in Iowa. Plant Dis. 80:57-60.

57. Robideau, G. P., de Cock, A. W. A. M., Coffey, M. D., Voglmayr, H., Brouwer, H., Bala, K., Chitty, D. W., Désaulniers, N., Eggertson, Q. A Gachon, C. M. M, Hu, C., Küpper, F. C., Rintoul, T. L., Sarhan, E., Verstappen, E. C. P., Zhang, Y., Bonants, P. J. M., Ristaino, J. B., and Lévesque, C. A. 2011. DNA barcoding of oomycetes with cytochrome $c$ oxidase subunit I and internal transcribed spacer. Mol. Ecol. Resour. 11:100-1011.

58. Ronquist, F., and Huelsenbeck, J. P. 2003. MrBayes 3: Bayesian phylogenetic inference under mixed models. Bioinformatics 19:1572-1574.

59. Salman, M., and Abuamsha, R. 2012. Potential for integrated biological and chemical control of damping-off disease caused by Pythium ultimum in tomato. Biol. Control 57:711-718.

60. Schroeder, K. L., Martin, F. N., De Cock, A. W. A. M., Levesque, C. A., Spies, C. F. J., Okubara, P. A., and Paulitz, T. C. 2013. Molecular detection and quantification of Pythium species: evolving taxonomy, new tools, and challenges. Plant Dis. 97:4-20.

61. Serrano, M. S., Fernández-Rebollo, P., Vita, P. D., Carbonero, M. D., Trapero, A., and Sánchez, M. E. 2010. Lupinus luteus, a new host of Phytophthora cinnamomi in Spanish oak-rangeland ecosystems. Eur. J. Plant Pathol. 128:149-152.

62. Shapiro, S. S., and Wilk, M. B. 1965. An analysis of variance test for normality (complete samples). Biometrika 52:591-611.

63. Spies, C. F. J., Mazzola, M., Botha, W. J., Langenhoven, S. D., Mostert, L., and McLeod, A. 2011. Molecular analyses of Pythium irregulare isolates from grapevines in South Africa suggest a single variable species. Fungal Biol. 115:1210-1224.

64. Spies, C. F. J., Mazzola, M., and McLeod, A. 2011. Characterisation and detection of Pythium and Phytophthora species associated with grapevines in South Africa. Eur. J. Plant Pathol. 131:103-119.

65. Suffert, F., and Guibert, M. 2007. The ecology of a Pythium community in relation to the epidemiology of carrot cavity spot. Appl. Soil Ecol. 35:488501.

66. Sweetingham, M. W. 1989.Fungi associated with root and hypocotyl diseases of seedling lupins in Western Australia. Aust. J. Agric. Res. 40:781789.

67. Tewoldemedhin, Y. T., Mazzola, M., Botha, W. J., Spies, C. F. J., and McLeod, A. 2011. Characterization of fungi (Fusarium and Rhizoctonia) and oomycetes (Phytophthora and Pythium) associated with apple orchards in South Africa. Eur. J. Plant Pathol. 130:215-229.

68. Van der Plaats-Niterink, A. J. 1981. Monograph of the genus Pythium. Stud. Mycol. 21:1-242.

69. Vincelli, P. C., and Lorbeer, J. W. 1990. Root rot of onion caused by Pythium irregulare and Pythium coloratum. Mycopathologia 111:67-72.

70. Von Broembsen, S. L., and Brits, G. J. 1985. Phytophthora root-rot of commercially cultivated proteas in South-Africa. Plant Dis. 69:211-213.

71. Whipps, J. M., and Lumsden, R. D. 1991. Biological control of Pythium species. Biocontrol Sci. Technol. 1:75-90.

72. White, T. J., Burns, T., Lee, S., and Taylor, J. 1990. Amplification and direct sequencing of fungal ribosomal RNA genes for phylogenetics. Pages 315 322 in: PCR Protocols: A Guide to Methods and Applications. M. A. Innis, D. H. Gelfand, J. J. Sninsky, T. J. White, eds. Academic Press, New York.

73. Zhang, B. Q., and Yang, X. B. 2000. Pathogenicity of Pythium populations from corn-soybean rotation fields. Plant Dis. 84:94-99. 